\title{
Pope Francis on Conscience, Gradualness, and Discernment: Adapting Amoris Laetitia for Business Ethics
}

\author{
Caleb Bernacchio \\ IESE Business School
}

\begin{abstract}
Experience often manifests a gap between moral principles that are both rationally defensible and widely accepted, and the actual practice of business. In this article, I adapt Pope Francis's discussion of conscience, gradualness, and discernment, in Amoris Laetitia, for the philosophical context of business ethics in order to better conceptualize and to identify means of narrowing the gap between objective moral principles and business practice. Specifically, right conscience allows for a better understanding of the scope and boundary conditions of moral principles, gradualness highlights the need to identify ways that moral principles can be properly implemented within organizations, and discernment draws attention to the importance of solidarity, in order to avoid one-sided, self-serving action descriptions. In these ways, Francis's discussion contributes to the narrowing of the gap between objective moral principles and business practice. I conclude by discussing ways that Francis's framework can inform business ethics courses.
\end{abstract}

KEY WORDS: conscience, discernment, moral agency, practical wisdom, Pope Francis, Amoris Laetitia

"The more right conscience holds sway, the more persons and groups turn aside from blind choice and strive to be guided by the objective norms of morality."

-Gaudium et Spes ${ }^{1}$

$I^{\text {n }}$ $n$ the world of business, as in life more generally, there is a real sense in which nothing is more important than the adoption of objective moral principles by ordinary persons in their everyday lives. The very idea of virtue embodies a commitment to the "noble," to a qualitatively distinct notion of goodness that does not weigh but rather "silences" rival considerations (McDowell, 1979: 335). Thus, the virtuous person would never balance the benefits of moral agency against the chance for success, personal satisfaction, or profit brought about by immoral means. Yet, almost every day we encounter clear instances of a divergence - a gap-between the moral principles defended by leading theories of business ethics and the everyday practice of business. From corporate scandals, mistreatment of employees, and unbridled greed to shirking, opportunism, and a quotidian disregard for the common good, the practice of business presents many discouraging examples of vice and immorality.

This gap raises questions for business ethics research concerning both the factors responsible for the divergence between moral principles and business practice and the means by which this gap can be closed. Answers to these questions are an integral 
element of normative theories of business ethics, insofar as the discipline pursues nothing less than the "transformation of private attitudes, mores, practices, and institutions," seeking an alignment between the practice of business and objective moral principles (Donaldson, 2015: 787). In this article, in order to better understand the factors responsible for this gap and to identify ways of narrowing it, I draw upon Pope Francis's recent discussion of conscience, gradualness, and discernment in Amoris Laetitia (henceforth AL), a document intended to address issues regarding marriage and family life in the context of the Catholic Church. AL is relevant to business ethics research precisely because it focuses on the struggles and conflicts inherent within the moral life, as imperfectly virtuous agents aim to embody objective moral principles in their daily lives.

Francis encourages ethicists to adopt a broader perspective, including both an analysis of objective moral principles and a much greater focus on the processes by which these principles are adopted and acted upon by ordinary persons, appreciating the gradual nature of moral development (Kelly, 2016). He also emphasizes the need to directly face the complexity of ordinary life and the potential for moral disagreement. Stating that "discernment redeems the necessary ambiguity of life," Francis (2013a: 14) highlights the need to appreciate the difficulties that ordinary persons face when engaging in moral reasoning and the corresponding need for ethicists to take steps to better inform this process. Thus, Francis's insights can enrich and extend business ethics research by placing much greater attention on the context of moral agency, the need for dynamic processes of moral development, and the ways in which business ethics research can inform ordinary businesspersons' processes of discernment.

$\mathrm{AL}$ focuses on problems concerning marriage and family from the perspective of Catholic theology and ecclesial practice. In order to refocus these insights onto the problems facing business ethics research, it is necessary to contextualize Francis's discussion of conscience within the more systematic perspective provided by the broader Thomist tradition of moral inquiry (for a general overview of the notion of conscience, see Grisez, 1983; May, 2003). In doing this, I develop a philosophical rather than theological account of conscience, explaining the role of a properly formed conscience and the way that this notion can inform business ethics research.

It should be noted that AL has proven highly controversial (see Biliniewicz, 2018 , for an overview of the dispute). ${ }^{2}$ Some have argued that, in his discussion of conscience, Francis has failed to adequately account for the importance of objective moral norms. In this article, while I cannot present a reading of AL in its entirety, I reject subjectivist readings of AL and emphasize its continuity with previous accounts of conscience in the Thomist tradition (for a comprehensive reading of AL along these lines, see Granados, Kampowski, \& Pérez-Soba, 2017). Instead, I focus on the way that ordinary businesspersons come to accept and to be motivated by objective moral principles (see John Paul II, 1993: 64).

While it is necessary to avoid relativism and subjectivism, an explicit focus on conscience enables researchers to better account for the way that normative principles are received by businesspersons within specific contexts of action. Thus, the focus on conscience, gradualness, and discernment in this article, far from a defense of 
relativism, provides a means of closing the gap between objective moral principles and business practice by illustrating the need to properly determine the scope of moral principles, account for moral development, such that moral principles come to be an inherent part of the life of an organization, and inform the discernment processes of ordinary businesspersons, enabling them to better perceive the ethical import of business practices. In this sense, the promotion of "right conscience" serves to further the influence of "the objective norms of morality"(Gaudium et Spes, 1965: 16). Thus, read in the context of the broader tradition of Catholic Social Teaching, AL provides important insights concerning the application of objective moral norms in the context of moral imperfection and ambiguity, such as that typical of business practice.

\section{CONSCIENCE AND MORAL TRUTH}

Francis's (2016: 37) claim that ethicists "have been called to form consciences, not to replace them," is the touchstone of his distinct approach to moral questions. Francis (2016: 305) encourages ordinary persons to identify "possible ways of . . growing in the midst of limits." Far from an acceptance of relativism, Francis maintains that we can only appreciate the potential means of moral progress in the light of moral truth (Granados et al., 2017). To understand these claims, it is first necessary to place Francis's account of moral development within the broader context of the Thomist tradition, as it has addressed the notion of conscience.

\section{Conscience in the Thomist Tradition}

Aquinas describes conscience as "knowledge applied to an individual case" (ST I, Q. 79, Art. 13, co.). At greater length, conscience can be defined as "a judgment, or practical command of reason, in which we judge something must be done here and now as a good, or something must be avoided as an evil" (Liguori, 2017 [1852]: 25). These traditional accounts highlight two aspects of the notion of conscience: knowledge of objective moral principles and the application of such principles to a specific situation or context of action.

Since conscience refers to the way that objective moral principles inform specific actions, its reduction to a mere subjective opinion trivializes this notion, rendering it irrelevant to the task of understanding how ordinary persons come to properly act upon objective moral principles within specific contexts (John Paul II, 1993: 32). Accordingly, conscience is fallible precisely because it is intrinsically directed to moral truth. Likewise, objective moral principles necessarily serve as the measure of judgments of conscience. Absent this link with objective moral truth, conscience becomes merely an arbitrary expression of subjective preference. Thus, while conscience provides a proximate norm of action-meaning that one must never act against a certain conscience - it is not the ultimate norm of action (John Paul II, 1993: 60). Instead, conscience presupposes, as its basis and source of authority, objective moral principles that must be appealed to in each judgment of conscience. In this way, conscience, when properly formed, directs one toward one's ultimate end (telos), what Aristotle (1999) calls human flourishing (eudaimonia). 
Francis (2016: 222), noting that the more that persons attempt "to listen in conscience to God and his commandments . . . the more their decision will be profoundly free of subjective caprice," brings out the second important aspect of this notion: conscience requires formation, a process of development enabling agents to better appreciate the normative force of objective moral principles. This process, whereby the "acting subject personally assimilates the truth contained in the law" (John Paul II, 1993: 52), involves the development of virtues, especially practical wisdom. Conscience involves the application of moral principles to specific situations. Thus, "only those who have the virtue of prudence possess right conscience" (Sultana, 2012: 620), since prudence enables agents to properly grasp the particular context of action (McDowell, 1998; Shotter \& Tsoukas, 2014). In this sense, conscience-in conjunction with the virtue of prudence-enables one to live well.

Traditionally, conscience has been divided into various modes including right, doubtful, and erroneous, among a number of others (Liguori, 2017 [1852]: 25). These differing modes of conscience are particularly important because they provide a range of categories capable of classifying the different ways in which ordinary persons relate to the objective moral principles defended by normative theories of business ethics. The imperfect modes of conscience, those involving doubt, ignorance, or moral weakness, must be understood in comparison with the notion of right conscience, a conscience that is properly formed, where objective moral principles are subjectively appropriated by the virtuous agent (John Paul II, 1993: 64). Thus, imperfect modes of conscience do not merely fail to express moral truth, but they also fail to direct one adequately to the end of human flourishing.

\section{Good Conscience and the Scope of Moral Norms}

The notion of a true or right conscience describes the situation where an agent adequately grasps objective moral norms and concretely implements them in her decisions. In a business context, it captures the notion of a virtuous businessperson who is able to properly apply objective moral principles in her business activities. As such, the notion of right conscience may also contribute to a better appreciation of the boundary conditions of relevant moral principles, defended within various theories of business ethics. Specifically, in cases where business practice seems to conflict with moral principles, an agent's conscientious judgments may reveal that, within a specific context, the conflict is only apparent and that considering all of the relevant concerns in a given situation, some specific moral principles need not apply, or merely apply in a more limited fashion.

For example, research drawing upon the MacIntyrean framework (Moore \& Beadle, 2006) has sought to identify practices within organizations that focus on common goods, the role of the virtues, and an ethos of "craftsmanship" (see Moore, 2005). Fernando and Moore (2015) draw upon this framework and conceptualize a local subsidiary of a global pharmaceutical company that produces healthcare products as a virtuous practice. But one can imagine a situation where production in this organization is transformed such that it comes to have none of the characteristics of a "craft," becoming, instead, essentially an assembly line. Workers are not abused, but they are not given the opportunity to participate in cooperative activities 
based upon common goods. Here, managers may recognize the shortcomings of this mode of production, the way it fails to promote moral development, and in this sense, there may appear to be a gap between the ideal of virtuous work and actual business practice, but managers may also realize that the firm will be unable to continue operating if the cost of production substantially increases. Thus, this example raises the question: In what sense is there really a gap between the moral ideal and actual practice?

Where work fails to exemplify the ideal (in this case, the ideal of virtuous "craftsmanship"), an appreciation of the notion of right conscience allows for a better understanding of the apparent gap between moral principles and actual business practice. For example, managers may recognize the limits of their mode of production but also realize that their organization provides employment to a substantial portion of the population, who would otherwise be unemployed. They may also realize that their firm provides affordable drugs that would otherwise be inaccessible to a substantial market segment. Understanding a case such as this from the perspective of the virtuous businessperson who manifests a right conscience may offer a different perspective, showing that, all things considered, this gap was merely apparent, since, for instance, urgent need makes the concern for virtuous work less relevant in this context (Bernacchio, 2018).

Though the average businessperson faces similar-if often less dramatic_-choices in a variety of contexts, my concern is not to decide the merits of this or any specific case, but to suggest that situations involving apparently conflicting moral concerns can only be properly understood from the perspective of the virtuous businessperson who manifests a right conscience, properly implementing moral principles within the context of her actions. Nor should one conclude that moral principles are simply overridden by situational concerns. Instead, right conscience, as an embodiment of moral truth within a specific situation, indicates the proper scope and boundary conditions of relevant moral principles. Returning to the example from above, a manager's valid judgment of conscience may indicate, considering all relevant factors in the situation, that needs are too urgent to focus on cultivating an ethos of craftsmanship. This sort of moral complexity is commonplace and can be accommodated within business ethics research by focusing on the notion of right conscience.

Thus, when businesspersons provide valid reasons for why their actions fail to exemplify a specific moral principle, their conscientious judgments show that a perceived gap between moral principles and business practices was merely apparent and can be overcome within a specific situation. Again, moral principles are not overridden, but are, rather, properly contextualized. In this way, businesspersons who manifest a right conscience provide a means of properly understanding how such principles should be implemented in a given context. And while this may seem trivial, in many cases a proper appreciation of context-from the perspective of the virtuous agent - may be more important than an explicit elaboration of the relevant moral principles (Aristotle, 1999, book 6.7; McDowell, 1979).

Similar considerations are likely to apply in other cases. Extending the example discussed above, the production of pharmaceuticals may result in some form of environmental damage, even from activities that are not legally prohibited. 
According to the market failures approach (Heath, 2006), managers have a moral obligation to avoid negative externalities, even those resulting from legal business activities. But in this case, managers face a choice between continuing to damage the environment or moving their operation, resulting, potentially, in broken promises to various stakeholders and a range of negative consequences. And, while there may be no easy solution in this case, managers and other businesspersons frequently face situations such as this, even if they may be less dramatic.

In such cases, it is necessary to appreciate the manifestations of businesspersons' conscientious judgments. Do such persons feel conflicted? Are they in doubt about their actions? Or do they feel satisfied that they have made the correct choice given the specific context of an action? In cases where agents are confident and when they are able to offer valid reasons for their decisions, such expressions of right conscience indicate how moral principles should be properly contextualized. Articulating the factors that figure into such choices can enrich and extend existing theories of business ethics by providing a better appreciation of the scope and boundary conditions of moral principles. Again, it is not that contextual factors override moral principles, but rather that only by appreciating context from the perspective of the virtuous businessperson's right conscience can we properly understand how to apply such principles. In these cases, a better appreciation of such judgments of conscience serves to close the apparent gap between moral principles and business practice.

Francis's notion of gradualness, discussed in the next section, complements this discussion of conscience in two ways. First, gradualness explicitly accounts for the fact that many agents fail to adequately embody objective moral principles in their judgments of conscience, thereby lacking a right conscience. This recognition of moral imperfection reinforces the fact that conscience is fallible and that appeals to conscience need not disregard objective moral principles. Second, by acknowledging the reality of moral imperfection, gradualness explicitly highlights the need for the formation of conscience.

\section{GRADUALNESS}

With his discussion of gradualness in AL, Francis aims to broaden the scope of moral inquiry from a static analysis to a dynamic, process-based perspective focused on the way that abstract moral principles are concretely implemented. The notion of gradualness indicates that the formation of conscience is always a work in progress. Francis explains this notion as "gradualness in the prudential exercise of free acts on the part of subjects who are not in a position to understand, appreciate, or fully carry out the objective demands of the law" (Francis, 2016: 295). In the context of business ethics, accounting for gradualness requires giving more room within normative theories to imperfectly motivated agency and developing models of moral improvement whereby imperfect agents gradually become able to properly implement objective moral principles through their actions, i.e., to manifest right conscience.

Francis had explicitly voiced similar concerns in an earlier document, stating that "realities are greater than ideas" and emphasizing the importance of "initiating processes" that "engage other persons and groups who can develop them to the 
point where they bear fruit" (2013b: 232, 223). Thus, processes of moral development are the means by which abstract principles are embodied within the realities of human life. These considerations extend the theme discussed in the previous section concerning the proper contextualization of moral principles, since it is only, insofar as moral principles are embodied in the conscientious judgments of virtuous agents, through such processes of moral development that we can properly appreciate their scope and concrete implications. Accordingly, concrete processes of moral development ensure that objective moral principles come to be adopted by imperfect moral agents such that they become an integral component of a form of life (Thompson, 2008) as it is embodied within an organization. Thus, Francis's focus on gradualness points to a further means of closing the gap between moral principles and business practice.

\section{Gradualness and Moral Development}

Properly acknowledging the need for gradualness and the reality of moral imperfection has important implications at both the individual and organizational levels. At the individual level, gradualness points to the importance of motivation, and specifically, in an organizational context, incentives. Theories of business ethics cannot presume that agents are perfectly virtuous, that they respond to "external," or objective reasons, independently of subjective motivational factors (McDowell, 2013), just as one does not assume that a child will exercise the same self-control as would the child's mother. And insofar as agents are not virtuous, such external motivational factors are important. Thus, we must always ask how a given theory of business ethics can be embodied by imperfectly motivated businesspersons (see also MacIntyre, 2007: 23). Ideally, organization members will gradually come to appreciate the intrinsic value of moral agency, but such an outcome should not be treated as a given, or initial, condition (see Tsoukas, 2018: 333).

In organizations, it is necessary to ask which incentives could plausibly enable imperfectly motivated organization members to gradually grasp relevant objective moral principles, defended within a given theory of business ethics. It is noteworthy, for instance, that when MacIntyre (2007: 188) introduces the concept of a practice, which has been influential within virtue-based approaches to business ethics (see Beadle, 2017; Sison \& Fontrodona, 2012: 228), he focuses on the role of external incentives, explaining how a child, with no interest in chess, could be motivated to play through the offer of candy, with the hope that she will gradually develop an appreciation for the intrinsic value of the game. But within business ethics research that draws upon this notion, there has been very little effort to explain the types of incentives that can best promote moral development, when organizations members are less than fully committed to the practice (see Beadle, 2017).

While avoiding a reductive and instrumental understanding of moral principles (Dobson, 1997), it is necessary to acknowledge the reality of moral imperfection and to identify means of promoting moral development. But incentives, understood broadly, need not be financial. One often overlooked way of incentivizing moral agency is through the use of awards (Frey \& Gallus, 2017). Firms might offer something as simple as a small plaque or an inexpensive prize, like a gift card each 
quarter, to an employee who manifests integrity, courage, or helping behavior beyond job requirements. This award could be given in a small ceremony or celebration. This type of incentive does not aim to provide adequate financial compensation for what could, at times, be costly behavior, but rather serves to provide recognition and praise to persons exercising moral agency, offering a slight external "nudge" that may enable less than virtuous agents to gradually appreciate the intrinsic value of moral principles.

This concern for recognition and praise is related to what Weaver (2006: 351) calls an "opportunity for moral agency," which can be understood as a situation where virtuous behavior is provoked or made salient by a particular organizational context. Opportunities for moral agency include simple situations where managers avoid excessive oversight, allowing, for example, employees to self-regulate the length of their breaks and the use of minor company resources, enabling them to gain a sense of responsibility, especially when organization members are given recognition for acting virtuously. But such opportunities also include more complex contexts where production is arranged such that employees necessarily rely upon each other to complete tasks, thus promoting cooperation and organizational citizenship behaviors.

For example, Volvo experimented with "autonomous assembly teams," allowing members to self-determine the allocation of tasks, the training and recruitment of new members, and appropriate quality control measures (Breen, 2012). Compaq adopted a similar approach (Eriksen \& Amit, 1996), as did many other firms. This type of autonomous team provides unique opportunities for moral agency beyond that of standard assembly-line techniques. In this context, team members are encouraged to think about how tasks can be allocated both fairly and efficiently, and in a way that does not waste company resources. Team members are also given the opportunity to personally appropriate standards of excellent work and to determine how the needs of customers should influence design choices. While providing such opportunities for moral agency may, at times, increase the cost of production, they not only promote moral development by enabling employees to develop "a sense of self-efficacy in virtue" (Weaver, 2006: 351), but they may also lead to other efficiency gains by minimizing moral hazard (Hartman, 1996) and by promoting information sharing (Uzzi, 1997) and commitment to group-level goals (Foss \& Lindenberg, 2013).

But it goes without saying that the type and intensity of financial incentives also matters, not least because it can affect the nature of the interaction between organization members (Foss \& Stea, 2014). Some forms of incentives may actually reduce the need for cooperation between employees, even within highly task-interdependent contexts (Puranam, 2018). For example, in the production of automobiles, the manner in which participants are integrated into the production process affects the extent of collaboration and the sharing of information (Shaiken, Lopez, \& Mankita, 1997). Thus, a team tasked with assembling an entire transmission will interact very differently than would several individuals, each tasked and incentivized to assemble a component part, i.e., the torque converter, pump, gearset, etc., before handing the components to another person tasked with assembling the completed transmission. Specifically, managerial efforts to individuate, more closely measure, and 
more strongly incentivize individually assigned tasks may lead to less cooperation between organization members (Puranam, 2018), thereby eliminating opportunities for moral agency (Weaver, 2006). The impact of varying incentives schemes suggests the likelihood of significant differences regarding the degree of moral agency present within organizations, even amongst those sharing cooperative, or practice-like (Moore, 2017), modes of production.

In a related example, the Lincoln Electric Company (see Roberts, 2004) used individually focused piece-rate compensation to motivate employees' individual tasks in the production of welding equipment, resulting in high levels of productivity. Lincoln paid a fixed amount for each unit produced by an individual employee, motivating some employees to continue working during lunch breaks. But Lincoln balanced this pay-for-performance focus on individual-level tasks with an equally strong bonus system (potentially matching pay from piece-rate compensation) that rewarded employees for cooperation and helping behavior directed toward struggling coworkers. But without the bonus system, even moderately altruistic employees at Lincoln are likely to have ignored the needs of coworkers because of the strong individual-level incentive system. As these examples illustrate, the quality of organization member interactions and, thus, the nature of the opportunities for moral agency provided by the organization, is highly dependent upon the incentives provided by the organization.

According to Francis, the reality of moral imperfection requires accompaniment by others, involving specific relationships that "promote growth" and moral development (2016: 223; see also Granados et al., 2017). Thus, acknowledging the importance of gradualness and the reality of moral imperfection involves the identification of organizational structures and relationships that enable moral principles to become embodied within organizational life. Such structures include awards and incentives schemes, as well as differing modes of production, that provide opportunities for moral agency. While general requirements may be difficult to specify because organizational structures interact in complex ways-i.e., high-powered individual-level incentives may be balanced with bonuses for cooperation-to account for gradualness and to explain how moral principles can be embodied within organizational life, theories of business ethics must be able to articulate the way in which specific moral principles can be facilitated by various formal structures, in a wide variety of organizations.

\section{Embodying Moral Principles in Organizational Life}

Francis's concern with gradualness also has implications at the organization level, specifically concerning organizational change, such that organizations create environments conducive to the adoption of specific moral principles by members. As noted above, this concern complements the previous consideration regarding the way that moral principles are given more specificity when they are embodied in businesspersons' conscientious judgments, by further focusing on the way that moral principles can be embodied in the life of an organization, becoming second nature to its members and operative within their conscientious judgments. As such, a focus on organizational change offers another means of closing the gap between moral principles and business practice. 
Grant and Patel (2012) offer an illustrative example of the way that business ethics research can account for gradualness, developing a process model explaining how helping norms can be implemented within organizations where norms of self-interest (Miller, 1999) are dominant. Norms of self-interest involve "shared beliefs that employees do_-and should — advance their own interests with little concern for the welfare and interests of others" (Grant \& Patel, 2012: 548-49). Their model explains how challengers - pro-socially motivated proponents of cooperation — can exemplify helping behavior, for example by assisting a coworker who is having difficulty completing a report, and then use this action as an opportunity to raise questions about the general role of helping behaviors within the organization. Given a context where norms of self-interest are operative, challengers might ask coworkers if and when they would help a fellow coworker facing a similar difficulty with a report or ask whether coworkers want to discuss their own work experiences in order to enable others to avoid similar problems.

Grant and Patel argue that by modeling helping behavior and then raising questions about its importance, norms of helping behavior may gradually come to replace norms of self-interest. While the details of this model are beyond the scope of my argument, the article offers an example of important questions that any theory of business ethics that takes seriously the need for gradualness must ask, i.e., questions about the specific actions that would be necessary if particular moral principles were to be adopted by organization members, or the steps that more virtuous members could plausibly take to ensure that imperfectly motivated fellow organization members may come to a greater appreciation of such moral principles. Again, these questions relate to Francis's claim that "realities are greater than ideas" (2013b: 232), emphasizing the need to identify plausible processes of organizational change whereby objective moral principles can become operative within a given organization.

In another example of a process model of moral development, Lawrence and Maitlis (2012: 654) "explore how an ethic of care might be enacted within organizations." According to the authors, an ethic of care can be embedded within organizational routines through narrative practices that involve an effort to discuss the positive aspects of team members' experiences, i.e., a project completed before a deadline or a customer that was particularly satisfied, in order to enhance the team's sense of efficacy and awareness of the capacity for agency. Coupled with efforts to acknowledge "the ubiquity of human vulnerability" and to contextualize the difficulties team members face when exercising collective agency, Lawrence and Maitlis (2012: 649) argue that such narrative practices can lead to the implementation of an ethics of care within organizations such that team members jointly frame future opportunities for shared agency in order to alleviate the needs of fellow members.

Again, the specific details of this model are beyond the scope of my argument, but the questions the authors raise could similarly be raised by any normative theory of business ethics: How might employee rights (Werhane, Radin, \& Bowie, 2003) or responsible political agency (Scherer \& Palazzo, 2011) become embodied within organizations? What steps might be taken to promote the adoption of such moral principles? 
And because of the need to contextualize moral principles within specific social contexts, elaborating the details of such models goes beyond sociological factors, involving a consideration of the issues discussed above concerning the identification of boundary conditions of moral principles (in relation to the notion of right conscience). In this way, normative and sociological questions are joined in an attempt to understand the way that specific norms may be embodied within particular organizations.

In an effort to critique stakeholder theory, Heath and Norman (2004: 262) offer indirect support for Francis's claims regarding the need to embed ethical principles within concrete social contexts when they argue that the implementation of stakeholder theory "requires radical reform of corporate governance structures and corporate law" in a manner that has many undesirable consequences. Thus, the authors argue that the inability to implement stakeholder theory in a capitalist context represents a decisive critique of this theory. I do not mean to endorse this specific critique, but it illustrates the need to account for the implementation of normative theories: insofar as the actual implementation of some theory of business ethics leads to ethically unwarranted implications, i.e., the marginalization of other ethically salient goals and social structures, or inadequate accounts of organization members' motivationsthus, failing to account for gradualness-doubts may be raised concerning the adequacy of the ethical claims made by the theory in question.

In other words, understanding how objective moral principles can actually be embodied within organizations involves both an appreciation of causal factors and conditions that may contribute to moral development, as well as a normative analysis of the proper manner of embodying specific moral principles within a given context. Accordingly, when linked with the notion of right conscience-concerning the identification of boundary conditions of the moral principles embodied within organizations - process models focused on moral development and organizational change offer important resources for addressing the concerns that Francis highlights with the notion of gradualness. Thus, in addition to identifying objective moral principles, theories of business ethics must explicitly account for the reality of moral imperfection and explain how a given organization, or organization member, could properly adopt a particular set of moral principles, within a given context. And so, as Francis argues, explanations for moral development and the formation of conscience will involve the identification of key processes and relationships (2016: 223; Granados et al., 2017) that promote such development. These considerations offer a further means of narrowing the gap between objective moral principles and the actual practice of business.

\section{DISCERNMENT}

An additional theme developed in AL that has the potential to further narrow the gap between objective moral principles and actual business practice is discernment. Discernment is not a particular method or formal procedure; instead, it refers to a process of reasoning that is oriented by solidarity and recognition of the humanity of others (Keenan, 2018; Gula, 1997) and sensitivity to the context of action, especially 
as this is revealed through one's emotions and experiences (Nussbaum, 1992) and as an acknowledgement of one's fallibility. Thus, Francis states that "discernment is dynamic; it must remain ever open to new stages of growth and to new decisions which can enable the ideal to be more fully realized" (2016: 333). Discernment links closely with the themes of conscience and gradualness, as it is the process by which judgments of conscience are made and an essential component of processes of moral development.

While not situated in an organizational context, Mark Twain's Adventures of Huckleberry Finn provides an illustrative example of the discernment process, which helpfully informs the application of this concept in business ethics. The main character Huck Finn, a young runaway, travels down the Mississippi River on a raft with an escaped slave named Jim. When the pair is reunited after a major accident on the river, Huck plays a cruel joke on Jim, convincing the latter that he had merely dreamed about the accident and then humiliating him further by coaxing him to offer an outlandish interpretation of the supposed dream. After the joke is up, Jim, the runaway slave, responds by explaining how thankful he had been when he realized that Huck was still alive, and telling him that "trash is what people is dat puts dirt on de head er dey fren's en makes 'em ashamed" (Twain, 2009: 65). After hearing Jim, and realizing that he had been made to feel ashamed and humiliated, Huck explains, "I didn't do him no more mean tricks, and I wouldn't done that one if I'd a knowed it would make him feel that way" (Twain, 2009: 65).

It is important to recall that Jim was a slave, someone not ordinarily recognized as a fellow human being by white Southerners like Huck. But after he apologized to Jim, Huck said that he "warn't ever sorry for it" (Twain, 2009: 65). What changed Huck for the better was his awareness of Jim's experience of humiliation and the way that this sparked his recognition of Jim as a fellow human being. Later, Huck expresses similar surprise when finds Jim sorrowing at the absence of his family, saying, "I do believe he cared just as much for his people as white folks does for their'n" (Twain, 2009: 117). Jim, Huck realized, was someone like himself, who could feel sorrow and suffer humiliation — a fellow human being.

\section{Discernment and the Context of Action}

Huck's recognition of, and solidarity with, Jim facilitated his discernment, leading the former to redescribe his action as a "mean trick," rather than a diverting joke that might be casually directed at a slave. In this way, the capacity to properly characterize or describe an action is linked with solidarity in the process of discernment, since it is through the recognition of others that it becomes possible to avoid one-sided, self-serving action descriptions. Thus, discernment is inherently social as it presupposes the recognition of others as fellow human beings whose concerns and experiences are equally worthy of consideration. And because of this, it also involves an acknowledgement of one's fallibility and a willingness to reevaluate one's judgments in the light of new experiences and the experiences of others.

In discussing the context of action, a central consideration in the discernment process, Francis states that "general rules set forth a good which can never be disregarded 
or neglected, but in their formulation they cannot provide absolutely for all particular situations" (2016: 304). In support of this claim, Francis appeals to Aquinas:

Although there is necessity in the general principles, the more we descend to matters of detail, the more frequently we encounter defects... In matters of action, truth or practical rectitude is not the same for all, as to matters of detail, but only as to the general principles; and where there is the same rectitude in matters of detail, it is not equally known to all... The principle will be found to fail, according as we descend further into detail (ST I-II, Q. 94, Art. 4; quoted at AL: 304).

Aquinas is here making the same point noted above (in the discussion of right conscience): that general principles are not overridden by circumstances, but, instead, that they may be seen to be inapplicable when the context is adequately specified (see also Nussbaum, 1992). Actions can be described in various ways (Anscombe, 2000; Davidson, 1963), and determining which moral principles apply within a given context requires a proper description of the action in question, which cannot itself be determined by further rules (Bowie, 2017: 20; Geach, 1977; Rhonheimer, 2000: 475-83). Aquinas explains this further, saying that in one action, that which "is taken as a circumstance added to the object that specifies the action, can," in another action, be taken "as the principal condition of the object that determines the action's species." In other words, the circumstances of a given action can change the object, or proper description, of an action. ${ }^{3}$

Aquinas's example involves theft from a church, which he argued is better described as sacrilege, but closer to our context, a decision to outsource some aspect of production, when it involves loyal employees who have made sacrifices for the firm, including investment in firm-specific human capital, may be better described as breaking a commitment to employees (Mayer, 2013). Likewise, a decision not to notify suppliers about a planned move so as to mitigate risk, may come to be seen as a type of unfaithfulness to one's friends (see Uzzi, 1997: 55). These cases can be seen as situations where the general fiduciary duty of managers to shareholders, which is a moral obligation (Bowie, 2017), is in need of proper contextualization and the determination of boundary conditions through the discernment process.

In each case, determining whether some proposed strategic plan is a faithful performance of the managerial role or a willful disregard of general moral norms (see Bowie \& Werhane, 2005, chapter one) requires solidarity with all those stakeholders who may be impacted by the decision, a recognition of their shared humanity, and a willingness to learn from their perspective so as to avoid one-sided and self-serving action descriptions, i.e., describing downsizing in order to give larger bonuses to executives as "capitalism" or a "matter of economics." Like the situation recounted in Huck Finn, the differing power and status of executives and managers, as compared with other stakeholders, makes solidarity and the recognition of others challenging. In this regard, Francis notes the importance of "listening to the things that happen, the feeling of the people, especially the poor" (2013a: 14), i.e., the importance of listening to persons with less power and influence.

Accordingly, engaging in the discernment process requires an acknowledgement of one's fallibility and a willingness to learn from others in light of one's experiences 
(Gula, 1997; Nussbaum, 1992). Just as Huck's capacity for empathy enabled him to feel Jim's shame and to register the evil involved in intentionally bringing it about, a manager's experiences of various stakeholders' emotional reactions to proposed courses of action provide an important input to the attempt to properly characterize a given action. Thus, managers should seek out opportunities to encounter those affected by their decisions, be they employees, suppliers, or other stakeholders in the community, in order to gain greater self-knowledge and to better understand their own actions. And it should be recalled that an acceptance of fallibility is not relativism, but a recognition of the need to properly contextualize general moral principles.

Francis says that discernment "involves striving untrammelled for all that is great, better and more beautiful, while at the same time being concerned for the little things, for each day's responsibilities and commitments" (2018: 169), a statement that perfectly captures the role of discernment within a business context. When properly understood, adherence to objective moral principles does not involve the rejection of the ordinary aims and tasks of business but places those considerations in a broader normative context. Through solidarity and attention to experience, discernment provides a way of grasping this broader context, and thus properly implementing objective moral principles.

\section{Moral Conflict and Invincible Ignorance}

While discernment may narrow the gap between moral principles and business practice, by enabling agents to avoid one-sided, self-serving action descriptions, practitioners and business ethicists are likely to face more far-reaching moral conflict stemming from a range of cultural factors that make it difficult to overcome moral error. Traditionally, intractable moral conflict was linked with the notion of invincible ignorance.

"An invincible conscience," notes Alphonsus Liguori, "is such that [it] cannot be morally conquered, since no thought or doubt comes into the mind of the one who acts, nor even confusion while he acts" (2017 [1852]: 26). Invincible ignorance describes an agent who acts wrongly but is not culpable because of various life experiences, cultural and religious traditions, and/or social conditions that prevent him or her from appreciating the validity of relevant objective moral principles. The term could easily be misleading, because it does not mean that one can never come to grasp the validity of relevant moral principles, but merely that one lacks the capacity in a given instance- - while he acts"- and as a result, is not culpable for a specific immoral action.

Business ethicists are likely to face various forms of invincible ignorance, which makes it difficult for persons to appreciate the force of explicit argumentation concerning moral principles. Thus, in order to address the gap between objective moral principles and business practice stemming from invincible ignorance, it is necessary to directly confront the sources of disagreement in a manner that is sensitive to the invincibly ignorant person's existing motivations and concerns. For example, Thomist proponents of virtuous work (Sison \& Fontrodona, 2012) are likely to encounter individualistic and instrumental conceptions of work, shaped by cultural 
beliefs concerning the link between the efficiency of markets and social welfare (Friedman, 1970), the separation of ethical questions from managerial decision making (Freeman, 1994; Hartman, 2011), or management theories excessively focused on opportunism and self-interest (Ferraro, Pfeffer, \& Sutton, 2005; Ghoshal, 2005). It is not so much that the theories and beliefs driving various forms of invincible ignorance in a business context are necessarily false - though some are-but rather that such beliefs and theories are often held in a manner that makes it difficult to reason about their proper application and to determine the legitimate implications that can be drawn from them, i.e., they are inadequately contextualized.

\section{Discernment and the Invincibly Ignorant Conscience}

One way that business ethicists can address the problem of invincible ignorance and further narrow the gap between objective moral principles and business practice is by taking steps to inform the discernment process of ordinary businesspersons. Francis encourages ethicists to adopt this perspective, arguing that ordinary persons "are capable of carrying out their own discernment in complex situations" and that a fundamental role of moral theory is "to form consciences, not to replace them" (2016: 37; see also Kelly, 2016).

Accordingly, the initial task for business ethicists addressing the invincibly ignorant conscience is to provoke doubts and questions about existing practices and currently held moral beliefs, attempting to open space for moral development. But specific arguments may be less effective than taking steps to help people "see clearly" the salient ethical factors that they have so far ignored (McDowell, 1979: 347). Duska (2014: 127) outlines a comparable view, saying that business ethics is less a matter of teaching "others a rule to be applied to this situation, but rather, to start where there is agreement or consensus, and have people look at the issue from the point of view that the evaluator uses to designate the object or action good or bad, right or wrong." This quote points to the importance of experience, but now the experience of the virtuous agent whose right conscience can help the inexperienced learn to see things in a new way.

Francis (2013a: 12) says that discernment is "an instrument of struggle," but to be effective when seeking to inform the discernment processes of the invincibly ignorant conscience, it is necessary to allow such persons to struggle with their own problems, seeking instead to find subtle ways to broaden the focus to include relevant moral considerations. This requires, firstly, an appreciation of the way that ordinary businesspersons understand the activities and routines characteristic of their work, and, secondly, an attempt to redescribe them in ways that make evident the relevance of specific moral principles. Thus, Huck redescribed his action as a "mean trick," making apparent its lack of kindness, just as a decision to downsize may, in some cases, be better described as a broken promise.

Beyond a concern for rhetoric (Duska, 2014), specifically the "thick evaluations" (Linden \& Freeman, 2017) used to redescribe actions, engaging with invincible ignorance requires a focus on contrasts as a way of making evident salient moral considerations. Thus, efforts to highlight the moral salience of helping norms may benefit both from modeling positive behavior, as Grant and Patil (2012) suggest, 
as well as by contrasting helping behavior with situations characterized by selfishness and lack of trust. These contrasts may enable businesspersons to see things from the perspective of a virtuous agent, whose right conscience manifests the application of objective moral principles within specific contexts of action.

A similar approach can be employed beyond the organizational context to enable businesspersons to see the ethical implications of economic activities as they relate to various stakeholders outside of the firm. Heath (2006) rightly defends the moral obligation of managers to minimize negative externalities stemming from legal business practices, but the term negative externality does little to capture the real impact of these harms on affected stakeholders and, thereby, little to enable imperfect moral agents to grasp this notion's moral importance. The appreciation of this norm by imperfectly virtuous businesspersons can be further facilitated by presenting contrasts between firms that have taken steps to avoid negative externalities and others that have ignored this norm.

Kering, a French multinational that owns a number of luxury brands and is a leader in sustainable investment, offers an example of a firm that has taken seriously the norms against imposing negative externalities on others, defended by Heath. As the firm has voluntarily sought to reduce its global environmental impact by 40 percent, in alignment with UN Sustainable Development Goals (Paton, 2017), it offers an instructive contrast with other firms that have failed to manifest similar concern for sustainability, i.e., BP, a firm whose careless mismanagement of drilling operations on the Deepwater Horizon oil rig released upwards of 490 million barrels of crude oil into the Gulf of Mexico, causing billions of dollars in damages and incalculable harm to the persons and wildlife in the area. By contrasting the positive role of sustainability goals in Kering, including the way that it contributes to organization members' sense of purpose (Grant, 2007), with the incalculable harm caused by BP's disregard for negative externalities-for example, by showing interviews with community members harmed by the spill—persons still unconvinced by Heath's (2006) arguments may come to call into question their presuppositions and reevaluate their disregard of negative externalities. Again, there is no formula for the discernment process, but sharp contrasts like this may help to overcome cultural factors that make it difficult to appreciate other modes of argumentation.

A similar approach can be taken toward issues concerning business and human rights (Arnold, 2010), ethical relationships within supply chains (Arnold \& Bowie, 2003), and the role of corporations in promoting just political institutions (Hsieh, 2009). In each case, efforts should be made to vividly describe both the experience of virtuous agents, who respond well in such situations, and the negative impact of the failure to appreciate the relevant ethical factors in these contexts. Discernment, Francis notes, demands that "great principles ... be embodied in the circumstances of place, time and people" (2013a: 12), but often it is only the perspective of the right conscience of the virtuous agent that makes it possible for others to appreciate how and why relevant moral principles should be embodied within a given context, in a specific way.

Likewise, Francis (2013a: 12) says that discernment is "an instrument of struggle," but this struggle must always be conducted from the perspective of the individual 
struggling with her own concerns. The moralist can hope to inform her process of discernment but not supplant it (see Francis, 2016: 37). And absent any link between ethical behavior and organizational performance, the ordinary businessperson may dismiss objective moral principles as irrelevant to daily practice (Freeman, 1999: 235; Margolis \& Walsh, 2003: 279-80). Thus, when attempting to address moral conflict related to invincible ignorance, there is a role for outlining the ways in which in sound ethical practices can promote profitability (see Barney \& Hansen 1994; Bowie, 2017).

While there is a danger of reducing business ethics to prudential concerns (Bowie, 2001: 291; Dobson, 1997), there should often be a link between virtue and success (Bowie, 2017; Moore, 2012, 2017), even if these are far from perfectly correlated. It is also important to note that other motives beside profitability may be equally or more important amongst ordinary businesspersons. Affinities for egalitarianism (Puranam, 2018), meaningfulness (Yeoman, 2014), and fairness (Fehr \& Schmidt, 1999) may offer similar sources of common ground for business ethicists to draw upon when engaging with ordinary businesspersons who fail to grasp the objective import of relevant moral principles.

Francis argues that the current "information-driven society" often "leads to remarkable superficiality in the area of moral discernment" (2013b: 64). This and other cultural factors may contribute to various forms of moral conflict and of invincible ignorance, making it difficult for ordinary businesspersons to appreciate the validity of relevant objective moral principles. In order to address these issues and further narrow the gap between moral principles and business practice, business ethicists must seek to inform the discernment process of ordinary businesspersons. This requires an acknowledgement of the importance of ordinary businesspersons' existing concerns, motivations, and legitimate aims. But discernment can also be improved by presenting contrasts between disastrous failures to observe and act upon relevant moral principles and laudable instances of virtuous action. In this latter case, businesspersons manifest right conscience by the way that they contextualize objective moral principles within concrete business contexts, enabling others to appreciate the moral salience of such principles.

\section{The Formation of Conscience in Business Ethics Courses}

Francis's account of conscience, gradualness, and discernment also has implications for teaching business ethics courses. First, students can only be led to adopt objective moral principles in judgments of conscience insofar as they as they first become of aware of their existing moral commitments. Gaining self-knowledge concerning one's habitual judgments and ethical commitments involves a growing awareness of the reasons that are taken to ground those judgments (Rödl, 2018), and once students are aware of the existing shape of their conscience, they can be asked whether their reasons are adequate. When students become aware of their ethical commitments, they can be challenged with the normative force of objective moral principles, elaborated in compelling arguments. Thus, an additional task for business ethics teachers is enabling students to gain better self-knowledge concerning their existing judgments of conscience. 
Instructors might use questionnaires or small-group discussions to provoke students to identify their existing ethical commitments. Likewise, throughout a course, where various ethical theories are presented and arguments are given for a range of moral principles, students should be encouraged to articulate their assessments of these arguments and, especially, the way that such principles relate to their own existing ethical commitments. Students should, at times, feel challenged by the arguments that are presented to them in a manner that differs from the way that students ordinarily relate to theories presented in other courses, i.e., operations or marketing. But they should also be made to understand the legitimacy of disagreement insofar as it can be grounded in compelling reasons (Adler, 2016), i.e., the fact that compelling arguments can, at times, be offered for conflicting courses of action.

In addition to enabling students to gain self-knowledge, business ethics courses should also aim to inform students' processes of discernment. This involves, on the one hand, the presentation of arguments, including challenges to students' existing ethical judgments and commitments and, on the other, efforts to enable students to perceive salient moral considerations from the perspective of the virtuous person (Duska, 2014: 127; McDowell, 1979: 347). In the Aristotelian tradition, moral perception is closely linked to the virtue of practical wisdom (2000, book 6.5). Thus, business ethics courses involve the development of practical wisdom (Hartman, 2006).

In this article, I have drawn upon Mark Twain's Huckleberry Finn to illustrate the role of discernment and moral perception. Similar examples could be used in business ethics courses. Few texts could provide more compelling support for the right to safe working conditions than Upton Sinclair's (2001) The Jungle, where meat-packers, working in the slaughter houses of Chicago in the early twentieth century, were treated little better than the animals that they were processing. Sinclair describes the horrible accidents, with lost limbs, and the dehumanizing conditions faced routinely faced by immigrant workers so as to avoid starvation. Thus, presenting students with compelling images of ethical considerations surrounding work provides a necessary counterpart to explicit argumentation.

Likewise, using contrasting examples of ethical considerations in business, both positive and negative, drawn from literature can inform the discernment processes of students, enabling them to better see salient ethical considerations that they might otherwise overlook. Charles Dickens famously uses contrasts in Hard Times for a related purpose, comparing Thomas Gradgrind, a crass utilitarian businessman, with Sissy Jupe, whose experiences in the circus gave her an appreciation for creativity, wonder, and compassion. Dickens (2003) describes Gragrind as a "man who proceeds upon the principle that two and two are four, and nothing over, and who is not to be talked into allowing for anything over," a man who could see no role for benevolence or mercy. Through the contrast of these characters, readers come to appreciate the moral limitations of Gradgrind's outlook, especially his lack of compassion and inability to value aspects of human life that cannot be quantified. Likewise, other examples could be drawn from films or TV shows. Contrasting images such as these may enable students to appreciate the role of objective moral principles in business practice from the perspective of the virtuous agents' right conscience, in a way that goes beyond the import of explicit argumentation. 


\section{CONCLUSION}

Experience often manifests a gap between moral principles that are both rationally defensible and widely accepted and the actual practice of business. In this article, I have adapted Pope Francis's discussion of conscience, gradualness, and discernment from its original theological context of marriage and family life in AL to the philosophical context of business ethics in order to better conceptualize and to identify means of narrowing the gap between moral principles and business practice.

Specifically, I have argued that the notion of right conscience better enables researchers to appreciate the boundary conditions of objective moral principles, indicating that at least some manifestations of such a gap are merely apparent. In these situations, moral principles are not overridden by circumstances but are, instead, properly contextualized by the virtuous agent's conscientious judgments. Similarly, I have argued that Francis's notion of gradualness highlights the reality of moral imperfection and the need for structures and processes within organizations that promote moral development. As such, gradualness suggests that theories of business ethics should explicitly identify the conditions by which a given theory can be embodied within organizations and identify the processes that make the adoption of such theories possible. While this approach involves a consideration of the causal factors contributing to the implementation of specific moral norms, it also raises specifically normative considerations concerning the boundary conditions and proper contextualization of such norms, thus linking gradualness with the notion of right conscience. Accordingly, Francis's notion of gradualness serves to narrow the gap between moral principles and business practice by identifying ways of promoting moral development amongst imperfectly virtuous businesspersons.

Finally, the notion of discernment provides an account of moral reasoning that goes beyond both formal models of decision making and most philosophical accounts of practical reasoning. Discernment draws attention to the importance of properly describing one's actions and the need for the solidarity and recognition of others (Keenan, 2018), in order to avoid one-sided, self-serving action descriptions. Through an acceptance of one's fallibility and by paying attention to one's experiences and especially the experiences of weaker parties, those Francis (2013a: 14) calls "the poor," one can gain a better sense of how relevant moral principles can be appropriately embodied within specific contexts.

In this light, business ethicists should aim to inform the discernment process of ordinary businesspersons, as well as students, by presenting contrasting images of virtuous businesspersons, whose judgments of conscience adequately embody objective moral principles in specific contexts of action and their less virtuous counterparts, whose disregard of relevant moral norms has had disastrous consequences for organizations and stakeholders. Such contrasts may enable businesspersons to "see clearly" (McDowell, 1979: 347) salient ethical considerations that they may otherwise overlook. Francis argues that ordinary persons "are capable of carrying out their own discernment in complex situations" and that ethicists should aim "to form consciences, not to replace them" (2016: 37). With its focus on conscience, gradualness, and discernment, Francis's AL offers a novel focus on conscientious 
judgment, moral imperfection, and fallible processes of discernment that can inform business ethicists' efforts to narrow the gap between objective moral principles and actual business practice.

\section{ACKNOWLEDGEMENTS}

I would like to thank Professor Norman Bowie and three anonymous reviewers, whose insightful comments greatly aided my efforts to improve earlier versions of this article. I also thank Marco D'Avenia and Robert Couch for helpful conversations and feedback.

\section{NOTES}

1. Gaudium et Spes., paragraph 16 (1965).

2. AL focuses on marriage and family life, but the most controversial elements of the document focus on questions in moral theology and ecclesial discipline surrounding the possibility of admitting divorced and remarried persons to the sacraments. Some prominent critics, including a number of cardinals, have argued that Francis has broken with traditional views on this question (see, for example, Douthat, 2018), while others have defended Francis's orthodoxy regarding these issues (see, for example, Buttglione, 2016; Ouellet, 2017). I have thought it best to avoid these issues in the present article, as they are both unrelated to relevant issues in business ethics and not directly connected to Francis's general claims about the importance of conscience, gradualness, and discernment.

3. Serge-Thomas Bonino (2016: 515), a leading theologian, faults Francis for failing to note the distinction between positive and negative moral precepts. Where positive precepts apply always but not in every circumstance, negative precepts apply always and in every case (see Finnis, 1991). But Bonino's criticisms miss the point of Francis's claims. Moral rules-both positive and negative-presuppose a proper description of the action's object (Geach, 1977; Rhonheimer, 2000: 475-83), which cannot itself be determined by further appeal to rules. For a traditional example, consider the difference between an unjustified homicide and capital punishment: whereas both scenarios involve acts that cause the death of a person, the additional circumstances in the latter case, regarding a just sentence issued by a lawful authority and the authority delegated to the executioner to carry out the sentence, change the object of the executioner's action causing the death of the condemned person such that it is an act of justice rather than murder. (In this example, I prescind from the question of the general justifiability of capital punishment.)

\section{REFERENCES}

Adler, P. S. 2016. 2015 Presidential address: Our teaching mission. Academy of Management Review, 41(2): 185-195.

Anscombe. G. E. M. 2000. Intention. Cambridge, MA: Harvard University Press.

Arnold, D. G. 2010. Transnational corporations and the duty to respect basic human rights. Business Ethics Quarterly, 20(3): 371-399.

Arnold, D. G., \& Bowie, N. E. 2003. Sweatshops and respect for persons. Business Ethics Quarterly, 13(2): 221-242.

Aquinas, T. 1981. Summa theologiae. New York: Christian Classics.

Aristotle. 1999. The Nichomachean ethics. T. Irwin (Ed.), Indianapolis, IN: Hackett Publishing Company, Inc.

Barney, J. B., \& Hansen, M. H. 1994. Trustworthiness as a source of competitive advantage. Strategic Management Journal, 15(S1): 175-190.

Beadle, R. 2017. MacIntyre's influence on business ethics. In A. Sison, G. Beabout, \& I. Ferrero (Eds.), Handbook of virtue ethics in business and management: 1-9. New York: Springer. 
Bernacchio. C. Networks of giving and receiving in an organizational context: Dependent Rational Animals and MacIntyrean business ethics. Business Ethics Quarterly, 28(4): 377-400.

Biliniewicz, M. 2018. Amoris Laetitia and the spirit of Vatican II: The source of controversy. London \& New York: Routledge.

Bonino, S. 2016. Saint Thomas Aquinas in the apostolic exhortation Amoris Laetitia. The Thomist, 80(4): 499-519.

Bowie, N. E. 2001. The role of business ethics: where next? Is there a role for academics? Business Ethics: A European Review, 10(4): 288-293.

Bowie, N. E. 2017. Business ethics: A Kantian perspective. Cambridge: Cambridge University Press.

Bowie, N. E., with Werhane, P. H. 2005. Management ethics. Oxford: Blackwell Publishing.

Breen, K. 2012. Production and productive reason. New Political Economy, 17(5): 611-632.

Davidson, D. 1963. Actions, reasons, and causes. The Journal of Philosophy, 60(23): 685-700.

Dickens, C. 2003. Hard times. London: Penguin Classics.

Dobson, J. 1997. Finance ethics. Lanham, MD: Rowman \& Littlefield Publishers.

Donaldson, T. 2015. Where the facts end: Richard De George and the rise of business ethics. Journal of Business Ethics. 127(4): 783-787.

Douthat, R. 2018. To change the church: Pope Francis and the future of Catholicism. New York: Simon \& Schuster.

Dow, G. K. 2003. Governing the firm: Workers' control in theory and practice. Cambridge: Cambridge University Press.

Duska, R. 2014. Why business ethics needs rhetoric: An Aristotelian perspective. Business Ethics Quarterly. 24(1): 119-134.

Eriksen, B., \& Amit, R. 1996. Strategic implications of business process re-engineering. In. N. J. Foss \& C. Knudsen (Eds.), Towards a competence theory of the firm: 97-110. London: Routledge.

Fehr, E., \& Schmidt, K. M. 1999. A theory of fairness, competition, and cooperation. The Quarterly Journal of Economics, 114(3): 817-868.

Fernando, M., \& Moore, G. 2015. MacIntyrean virtue ethics in business: a cross-cultural comparison. Journal of Business Ethics, 132(1): 185-202.

Ferraro, F., Pfeffer, J., \& Sutton, R. I. 2005. Economics language and assumptions: How theories can become self-fulfilling. Academy of Management Review, 30(1): 8-24.

Finnis, J. 1991. Moral absolutes: Tradition, revision, and truth. Washington, DC: Catholic University Press.

Flannery, K. L., \& Berg, T. V. 2018. Amoris Laetitia, pastoral discernment, and Thomas Aquinas. Nova et Vetera, 16(1): 81-111.

Fontradona, J., \& Sison, A. 2006. The nature of the firm, agency theory and shareholder theory: A critique from philosophical anthropology. Journal of Business Ethics, 66(1): 33-42.

Foss, N. J., \& Lindenberg, S. 2013. Microfoundations for strategy: A goal-framing perspective on the drivers of value creation. Academy of Management Perspectives, 27(2): 85-102.

Foss, N., \& Stea, D. 2014. Putting a realistic theory of mind into agency theory: Implications for reward design and management in principal-agent relations. European Management Review, 11(1): 101-116.

Francis. 2013a. A big heart open to God. San Francisco: Harper One.

Francis. 2013b. Evangelii gaudium. http://w2.vatican.va/content/francesco/en/apost_ exhortations/documents/papa-francesco_esortazione-ap_20131124_evangeliigaudium.html. 
Francis. 2016. Amoris laetitia. https://w2.vatican.va/content/dam/francesco/pdf/apost_ exhortations/documents/papa-francesco_esortazione-ap_20160319_amorislaetitia_en.pdf.

Francis. 2018. Gaudete et exsultate. http://w2.vatican.va/content/francesco/en/apost_ exhortations/documents/papa-francesco_esortazione-ap_20180319_gaudete-etexsultate.html.

Freeman, R. E. 1994. The politics of stakeholder theory: Some future directions. Business Ethics Quarterly, 4(4): 409-421.

Freeman, E. 1999. Divergent stakeholder theory. Academy of Management Review, 24(2): 233-236.

Frémeaux, S., \& Michelson, G. 2017. The common good of the firm and humanistic management: Conscious capitalism and economy of communion. Journal of Business Ethics, 145(4): 701-709.

Friedman, M. 1970. The social responsibility of business is to increase its profits. The New York Times Magazine.

Frey, B. S., \& Gallus, J. 2017. Honours versus money: The economics of awards. Oxford: Oxford University Press.

Gaudium et spes. 1965. http://www.vatican.va/archive/hist_councils/ii_vatican_council/ documents/vat-ii_const_19651207_gaudium-et-spes_en.html.

Ghoshal, S. 2005. Bad management theories are destroying good management practices. Academy of Management Learning \& Education, 4(1): 75-91.

Geach, P. 1977. The virtues: The Stanton lectures 1973-1974. Cambridge: Cambridge University Press.

Granados, J., Kampowski, S., \& Pérez-Soba, J.J. 2017. Accompanying, discerning, integrating: A handbook for the pastoral care of the family according to Amoris Laetitia. Steubenville, OH: Emmaus Road Publishing.

Grant, A. M. 2007. Relational job design and the motivation to make a prosocial difference. Academy of Management Review, 32(2): 393-417.

Grant, A., \& Patil, S. 2012. Challenging the norm of self-interest: Minority influence and transitions to helping norms in work units. Academy of Management Review, 37(4): 547-568.

Grisez, G. G. 1983. The way of the Lord Jesus, volume 1: Christian moral principles. Chicago: Franciscan Herald Press.

Gula, R. M. 1997. Moral discernment: Moral decisions guide. Mahwah, NJ: Paulist Press.

Hartman, E. M. 1996. Organizational ethics and the good life. Oxford: Oxford University Press.

Hartman, E. M. 2006. Can we teach character? An Aristotelian answer. Academy of Management Learning \& Education, 5(1): 68-81.

Hartman, E. M. 2011. Virtue, profit, and the separation thesis: An Aristotelian view. Journal of Business Ethics, 99(1): 5-17.

Heath, J. 2006. Business ethics without stakeholders. Business Ethics Quarterly, 16(4): 533-557.

Heath, J., \& Norman, W. 2004. Stakeholder theory, corporate governance and public management: What can the history of state-run enterprises teach us in the postEnron era?. Journal of Business Ethics, 53(3): 247-265.

Hsieh, N. H. 2009. Does global business have a responsibility to promote just institutions?. Business Ethics Quarterly, 19(2): 251-273.

John Paul II. 1981. Laborem exercens. http://w2.vatican.va/content/john-paul-ii/en/ encyclicals/documents/hf_jp-ii_enc_14091981_laborem-exercens.html. 
John Paul II. 1993. Veritatis splendor. http://w2.vatican.va/content/john-paulii/en/ encyclicals/documents/hf_jpii_enc_06081993_veritatis-splendor.html.

Keat, R. 2008. Practices, firms and varieties of capitalism. Philosophy of Management, 7(1): 77-91.

Keenan, J. F. 2018. Moral discernment in history. Theological Studies, 79(3): 668-679.

Kelly, C. M. 2016. The role of the moral theologian in the church: A proposal in the light of Amoris Laetitia. Theological Studies, 77(4): 922-948.

Lawrence, T. B., \& Maitlis, S. 2012. Care and possibility: Enacting an ethic of care through narrative practice. Academy of Management Review, 37(4): 641-663.

Liguori, A. 2017 [1852]. Moral theology, volume 1. Post Falls, ID: Mediatrix Press.

Linden, B. van der, \& Freeman, R. E. 2017. Profit and other values: Thick evaluation in decision making. Business Ethics Quarterly, 27(3): 353-379.

MacIntyre, A. 2007. After virtue: A study in moral theory, third edition. Notre Dame, IN: University of Notre Dame Press.

Margolis, J., \& Walsh, J. 2003. Misery loves companies: Rethinking social initiatives by business. Organization Science, 48(2): 268-305.

May, W. 2003. An introduction to moral theology. Huntington, IN: Our Sunday Visitor.

Mayer, C. 2013. Firm commitment: Why the corporation is failing us and how to restore trust in it. Oxford: Oxford University Press.

McDowell, J. 1979. Virtue and reason. The Monist, 62(3): 331-350.

McDowell, J. 1998. Some issues in Aristotle's moral psychology. Ethics, 4(107): $107-128$.

McDowell, J. 2013. Deliberation and moral development in Aristotle's Ethics. In The engaged intellect: 41-58. Cambridge, MA: Harvard University Press.

Miller, D. 1999. The norm of self-interest. American Psychologist, 54(12): 1053-1060.

Moore, G. 2005. Humanizing business: A modern virtues ethics approach. Business Ethics Quarterly, 15(2): 237-255.

Moore, G. 2012. Virtue in business: Alliance Boots and an empirical exploration of MacIntyre's conceptual framework. Organization Studies, 33(3): 363-387.

Moore, G. 2017. Virtue at work: Ethics for individuals, managers, and organizations. Cambridge: Cambridge University Press.

Moore, G., \& Beadle, R. 2006. In search of organizational virtue in business: Agents, goods, practices, and environments. Organization Studies, 27(3): 369-389.

Nussbaum, M. 1992. The discernment of perception: An Aristotelian conception of private and public rationality. In Love's knowledge: Essays on philosophy and literature: 54-105. Oxford: Oxford University Press.

Paton, E. 2017. François-Henri Pinault, Kering Chief, on why green is the new black. The New York Times, January 25.

Puranam, P. 2018. The microstructure of organizations. Cambridge: Cambridge University Press.

Rhonheimer, M. 2000. Natural law and practical reason: a Thomist view of moral autonomy. New York: Fordham University Press.

Robson, A. 2015. Constancy and integrity: (un) measurable virtues? Business Ethics: A European Review, 24(S2): S115-S129.

Rödl, S. 2018. Self-Consciousness and objectivity: An introduction to absolute idealism. Cambridge, MA: Harvard University Press.

Roberts, J. 2004. The modern firm: Organizational design for performance and growth. Oxford: Oxford University Press. 
Scherer, A.G., \& Palazzo, G. 2011. The new political role of business in a globalized world: A review of a new perspective on CSR and its implications for the firm, governance, and democracy. Journal of Management Studies, 48(4): 899-931.

Shaiken, H., Lopez, S., \& Mankita, I. 1997. Two routes to team production: Saturn and Chrysler compared. Industrial Relations: A Journal of Economy and Society, 36(1): 17-45.

Shotter, J., \& Tsoukas, H. 2014. In search of phronesis: Leadership and the art of judgment. Academy of Management Learning \& Education, 13(2): 224-243.

Sinclair, U. 2001. The jungle. Mineola, NY: Dover Publications.

Sison, A. J., \& Fontrodona, J. 2012. The common good of the firm in the AristotelianThomistic tradition. Business Ethics Quarterly, 22(2): 211-246.

Sultana, M. 2012. On conscience and prudence. The Heythrop Journal, 56(4): 619-628.

Thompson, M. 2008. Life and action: Elementary structures of practice and practical thought. Cambridge, MA: Harvard University Press.

Tsoukas. H. 2018. Strategy and virtue: Developing strategy-as-practice through virtue ethics. Strategic Organization, 16(3) 323-351.

Twain, M. 2009. Adventures of Huckleberry Finn. Mineola, NY: Dover Publishing.

Uzzi, B. 1997. Social structure and competition in interfirm networks: The paradox of embeddedness. Administrative Science Quarterly: 42(1): 35-67.

Weaver, G. 2006. Virtue in organizations: Moral identity as a foundation for moral agency. Organization Studies, 27(3): 341-368.

Werhane, P., Radin, T.J., \& Bowie, N.E., 2004. Employment and employee rights. London: Blackwell Publishing Ltd.

Williams, B. 2005. Realism and moralism in political theory: Two models of political theory. In G. Hawthorn (Ed.), In the beginning was the deed: 1-17. Cambridge: Cambridge University Press.

Yeoman, R. 2014. Conceptualising meaningful work as a fundamental human need. Journal of Business Ethics, 125(2): 1-17. 